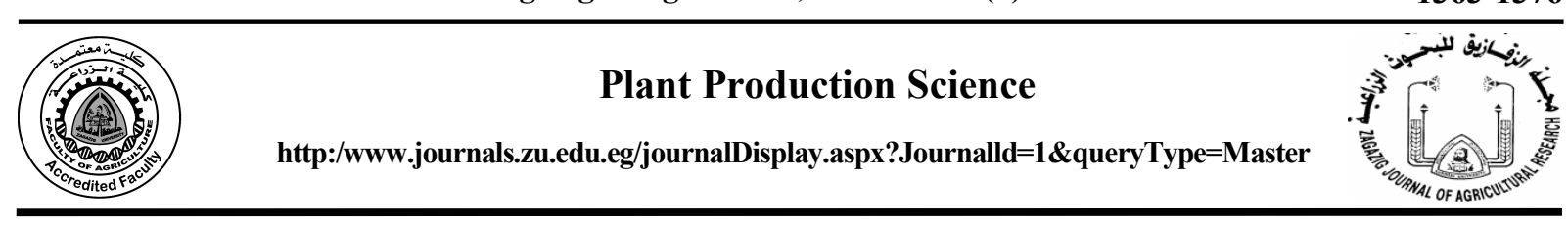

\title{
EFFECT OF SOME ESSENTIAL OILS USED AS ALTERNATIVE SWEET POTATO SPROUT CONTROL DURING STORAGE
}

\author{
Saleh M. Abou-Elwafa and M.A. Rageh* \\ Post. and Handling of Veg. Crops Dept., Hort. Res. Inst., Agric. Res. Cent., Giza, Egypt
}

Received: 01/07/2019; Accepted: 20/08/2019

\begin{abstract}
This study was carried out during two successive seasons of 2017/2018 and 2018/ 2019 on sweet potato roots of Beauregard cultivar which harvested at fully mature stage to evaluate the performance of jasmine oil, mint oil and clove oil at the concentrations of $100 \mathrm{ppm}$ during storage as a natural alternative to chlorpropham (CIPC) at the concentrations of $50 \mathrm{ppm}$ for control sprouting and maintaining quality of sweet potato roots stored at $13^{\circ} \mathrm{C}$ and $90 \%$ relative humidity $(\mathrm{RH})$ for 5 months plus 7 days at $20^{\circ} \mathrm{C}$ and $75 \% \mathrm{RH}$ (shelf life). The results showed that the percentage of weight loss, sprouting and decay score were increased with prolonging the storage period, while roots general appearance (score), total sugar content and total carotene content were decreased with time of storage. All treatments retained roots weight during storage as compared with the control (untreated) roots. No sprouts and decay were observed with jasmine oil and CIPC treatments in all storage periods, while these characters started to be shown early after two months in sprouting and after 3 months in decay of storage with untreated roots (control). Roots treated with jasmine oil or chlorpropham treatments were the most effective for maintaining general appearance followed clove oil and mint oil, while untreated roots (control) recorded the lowest one. Sweet potato roots treated with jasmine oil and CIPC treatments were significantly higher in total carotene content as compared with the other treatments. The results suggest that sweet potato roots treated with jasmine oil at $100 \mathrm{ppm}$ was a promising technique as natural alternative to CIPC for control sprouting and maintenance quality during storage at $13^{\circ} \mathrm{C}$ and $90 \% \mathrm{RH}$ for 5 months plus 7 days at $20^{\circ} \mathrm{C}$ and $75 \% \mathrm{RH}$ (shelf life).
\end{abstract}

Key words: Sweet potato, sprouting, quality, essential oils and CIPC.

\section{INTRODUCTION}

Sprouting is a major of losses in stored sweet potato, not only sprouting reduce the number of marketable sweet potato, but intense evaporation of water from sprout surface also reduces the weight of the remaining roots (Teper-Bamnolker et al., 2010). Visible sprouts on sweet potato are unacceptable to consumers. Nevertheless, for producers, suppression of sprout growth during storage is absolutely necessary to maintain market quality of the processed products (El-Sayed et al., 2013).

Inhibition of sweet potato sprouting during storage with using sprout-preventing chemicals probably delays metabolic changes in potato

\footnotetext{
*Corresponding author: Tel. : +201148873623

E-mail address: mrageh1@yahoo.com
}

tubers (Sugri et al., 2017). Many chemical compounds are known to inhibit sprouting. The sprout inhibitors chlorpropham (CIPC) have proved to be of value (Buitelaar, 1987; Yada $\boldsymbol{e t}$ al., 1991) (CIPC), is a commonly used postharvest sprout inhibitor. CIPC is applied to bulk sweet potato in storage as an aerosol at rates of 17 to $22 \mathrm{ppm}$ at $10-12^{\circ} \mathrm{C}$ (Sugri et al., 2017). However, their application can be problematic. Due to environmental concerns, in several countries use of CIPC and other chemicals are either restricted or may become restricted (Afek and Warshavsky, 1998). CIPC acts as a mitotic inhibitor by interfering the process of spindle formation during the cell division, it is known to inhibit protein synthesis, RNA synthesis, activity of $\beta$-amylase along with suppression of 
transpiration and respiration and interfere with oxidative phosphorylation and photosynthesis (Vaughn and Lehnen, 1991). CIPC is usually applied as a postharvest fogging treatment on stored sweet potato (Sugri et al., 2017).

Alternative sprout inhibitors of CIPC continue to be evaluated oils of some herbs and spices essential oils have been shown to reduce sprouting in sweet potato and can be applied to certified organic crops (Teper-Bamnolker et al., 2010). Essential oils (e.g., jasmine, mint, and clove) materials are now promoted (Zhang et al., 2002). Essential Oils (EO) are volatile, natural, complex compounds characterized by a strong odour and are formed by aromatic plants as secondary metabolites. However, repeated application of these compounds may be necessary for efficacy. Substituted naphthalenes (e.g., dimethyl naphthalene, diisopropyl naphthalene) may help reduce the amount of CIPC applied or the dependency on CIPC for sprout suppression at storage (Sugri et al., 2017).

Clove oil is also being investigated as a potential sprout suppressant and disease control agent found that treatments with clove had antisprouting activity on potato tuber at $8^{\circ} \mathrm{C}$ until day 105 (Afify et al., 2012).

Clove oil can be used effectively for potato sprout control but multiple applications at three week intervals will be required for long- term suppression (Frazier et al., 2006). The sprout suppressant properties of clove oil are ideal for an organic crop or a crop destined for export to a country that does not allow CIPC. Another use for this product may be to remove sprouts if a failure of traditional sprout control methods has occurred (Olsen et al., 2004). The active of ingredient of clove oil is eugenol and other eugenol-based components in the distillate produce (Afify et al., 2012). Also, clove oil have been shown to inhibit growth of fusarium sambucinum on potato (Frazier et al., 2006) and sprouting of potato (Olsen et al., 2004), without degrading the color or quality of potato products (Elsadr and Waterer, 2005; Frazier et al., 2006) reduced the incidence and severity of silver scurf on the surface of a tuber during storage when applied frequently (Olsen et al., 2004).

Mint oil is using recently as a natural sprout inhibitor and good alternative to sprout preventing chemicals such as isopropyl 3-chlorophenylcarbamate (CIPC) (Kleinkopf $\boldsymbol{e t}$ al., 2003), especially as it is environmentally friendly. Mint oil is one of the essential oils containing components (monoterpens, carvone) used and proved as efficient sprout suppressive, antioxidant and antimicrobial actions (Coleman, et al., 2001; Elbashir et al., 2011).

Recently, a new growth regulator, jasmine oil, was found to have growth-inhibiting properties (Parthier, 1991). Jasmine oil is a naturally occurring substance which derives from linoleic acid (Vick and Zimmerman, 1984) and occurs ubiquitously in plants (Meyer et al., 1984). Many biochemical and physiological reactions are affected by jasmonates including inhibition of seed germination and root growth, stimulation of chlorophyll degradation, promotion of leaf abscission, inhibition of flower bud formation, and enhancement of fruit ripening (Wang, 1998).

This comparative study evaluated the performance of some essential oils (jasmine, mint and clove) as natural alternative to CIPC to control sprouting and maintenance quality in treated sweet potato roots kept at $13^{\circ} \mathrm{C}$ and $90 \%$ RH for 5 months plus 7 days at $20^{\circ} \mathrm{C}$ and $75 \%$ $\mathrm{RH}$ (shelf life).

\section{MATERIAL AND METHODS}

Tuber roots of sweet potatoes (Ipomoea batatas L. Lam) $c v$. Beauregard were harvested at fully mature stage on september $24^{\text {th }}$ and $27^{\text {th }}$ in 2017 and 2018 seasons, respectively form Private Farm, Kaha District, Kaluobia Governorate, Egypt, then transferred to the laboratory of the Department of Vegetable Handling and Postharvest Research Section, Horticultural Research Institute, sorted and cured at $29 \pm 1{ }^{\circ} \mathrm{C}$ and $90-95 \%$ relative humidity $(\mathrm{RH})$ for 10 days, after curing, healthy uniform roots were selected and exposed to the following treatments.

1. CIPC at $50 \mathrm{ppm}$.

2. Jasmine oil at $100 \mathrm{ppm}$.

3. Mint oil at $100 \mathrm{ppm}$.

4. Clove oil at $100 \mathrm{ppm}$.

5. Control (untreated). 
All the previous treatments were applied with spray as fog over the roots at $25^{\circ} \mathrm{C}$ and $80 \% \mathrm{RH}$. Essential oils (Jasmine, mint and clove) was emulsified by tween 20 at dose $1 \mathrm{ml} / \mathrm{L}$. All the samples of sweet potato roots were packed in mesh bags and each had $2 \mathrm{~kg}$ (12-14 roots) represented as one replicate, fifteen replications were prepared for each treatment.

The samples were arranged in a complete randomized design and stored at $13^{\circ} \mathrm{C}$ and $90 \%$ RH for 5 months plus 7 days at $20^{\circ} \mathrm{C}$ and $75 \%$ $\mathrm{RH}$ (shelf life). The treatments were repeated every one month interval during the storage term. Samples were taken at random in three replications and evaluated every one month at $13^{\circ} \mathrm{C}$ and $90 \% \mathrm{RH}$ plus 7 days at $20^{\circ} \mathrm{C}$ and $75 \%$ $\mathrm{RH}$ (self life) intervals to determine:

\section{Physical Analysis}

\section{Weight loss (\%)}

It was calculated according to the following equation:

$$
=\frac{\begin{array}{l}
\text { Weight loss }(\%) \\
\text { Initial weight of roots- weight of roots at sampling date }
\end{array}}{\text { Initial weight of roots }} \times 100
$$

\section{Sprouting (\%)}

Sprouting percentage by counting the number of sprouts. A tuber considered sprouted when it had at least one sprout of $2 \mathrm{~mm}$ length (Wenzhong et al., 2004).

\section{Decay (score)}

A11 roots in each treatment were assessed for the percentage of surface showing visible rotting. Decay was determined as score $1=$ none, $2=$ slight (less than 10\%), $3=$ moderate $(10-$ $20 \%), 4=$ moderately severe $(30 \%), 5=$ severe (more than 30\%) (Wenzhong et al., 2004).

\section{General appearance (score)}

General appearance was determined according to the following score system of $9=$ excellent, 7 $=$ good, 5 = fair, $3=$ poor, and 1 : un salable.

\section{Chemical Composition}

\section{Total caroten content}

Was determined on $5 \mathrm{~g}$ of grated tissue which was homogenized (from $100 \mathrm{~g}$ grated flesh by mixer) with $50 \mathrm{ml}$ of acetone and filtered. The optical density of the filtrate was determined at $440 \mathrm{~m} \mu$ with spectrophotometer, according to Matissek et al. (1992).

\section{Total sugar content}

Fructose, glucose and sucrose were determined by HPLC Hewlett Packard series 1050 instrument, as described in AOAC (1975).

\section{Statistical Analysis}

The experiment was factorial with 2 factors in a complete randomized design (CRD) with 3 replicates. Comparison between means was evaluated by Duncan's Multiple Range Test at $5 \%$ level of significance. The statistical analysis was performed according to Snedecor and Cochran (1982).

\section{RESULTS AND DISCUSSION}

\section{Weight Loss (\%)}

Water loss is an important physiological process that affects the main quality attributes of sweet potato. The phenomenon causes shrinkage when it becomes excessive. The weight reduction of sweet potato during storage is shown in Table 1 . Generally speaking, there was reduction in weight in all samples as the time increased. Weight loss is a common phenomenon which occurs mainly due to moisture loss and loss of carbon reserves due to respiration (El-Sayed $\boldsymbol{e t}$ al., 2013). Concerning the effect of postharvest treatments, results revealed significant differences among treatments in weight loss (\%) during storage, all treatments reduced weight loss (\%) as compared with untreated (control). Moreover, sweet potato treated with jasmine oil or CIPC was the most effective treatments for reducing the weight loss during storage with no significant differences between them, followed by clove oil treatment while mint oil was less effective in this concern. However, the highest value of weight loss was obtained from untreated control. These results were true in the two seasons and in agreement with Wang (1998) for Jasmine oil, Sugri et al. (2017) for CIPC and Song (2009) for clove oil and mint oil.

The reduced weight loss was associated with the inhibition of sprouting by jasmine oil, and is probably the result of an indirect effect. 
Table 1. Effect of some essential oils and chlorpropham on weight loss (\%) of sweet potato roots during storage at $13^{\circ} \mathrm{C}$ plus 7 days at $20^{\circ} \mathrm{C}$ in $2017 / 2018$ and 2018/2019 seasons

\begin{tabular}{lcccccc}
\hline Treatment & \multicolumn{5}{c}{ Storage period (month) + 7 days shelf life } \\
\cline { 2 - 5 } & $\mathbf{1 + 7}$ days & $\mathbf{2 + 7 d a y s}$ & $\mathbf{3 + 7 d a y s}$ & $\mathbf{4 + 7 d a y s}$ & $\mathbf{5 + 7 d a y s}$ & Mean \\
\hline \multirow{2}{*}{ Jasmine oil (100 ppm) } & $3.80 \mathrm{q}$ & $5.73 \mathrm{o}$ & $7.73 \mathrm{k}$ & $9.08 \mathrm{i}$ & $10.90 \mathrm{f}$ & $7.45 \mathrm{D}$ \\
Mint oil (100 ppm) & $4.15 \mathrm{q}$ & $6.23 \mathrm{mn}$ & $8.40 \mathrm{j}$ & $10.27 \mathrm{~g}$ & $11.60 \mathrm{e}$ & $8.13 \mathrm{C}$ \\
Clove oil 100 ppm & $4.60 \mathrm{p}$ & $6.57 \mathrm{~m}$ & $8.80 \mathrm{i}$ & $10.50 \mathrm{~g}$ & $11.90 \mathrm{e}$ & $8.47 \mathrm{~B}$ \\
Chlorpropham (50 ppm) & $3.87 \mathrm{q}$ & $5.90 \mathrm{no}$ & $7.83 \mathrm{k}$ & $9.12 \mathrm{i}$ & $11.07 \mathrm{f}$ & $7.56 \mathrm{D}$ \\
Untreated (control) & $4.88 \mathrm{p}$ & 7.171 & $9.67 \mathrm{~h}$ & $11.20 \mathrm{f}$ & $12.47 \mathrm{~d}$ & $9.08 \mathrm{~A}$ \\
Mean & $4.26 \mathrm{E}$ & $6.32 \mathrm{D}$ & $8.49 \mathrm{C}$ & $10.03 \mathrm{~B}$ & $11.59 \mathrm{~A}$ & \\
& & & $\mathbf{2 0 1 8} / \mathbf{2 0 1 9}$ & & \\
Jasmine oil (100 ppm) & $3.73 \mathrm{r}$ & $5.53 \mathrm{o}$ & 7.501 & $8.77 \mathrm{i}$ & $10.60 \mathrm{f}$ & $7.23 \mathrm{D}$ \\
Mint oil (100 ppm) & $4.00 \mathrm{qr}$ & $6.10 \mathrm{n}$ & $8.15 \mathrm{jk}$ & $9.97 \mathrm{gh}$ & $11.17 \mathrm{de}$ & $7.89 \mathrm{C}$ \\
Clove oil (100 ppm) & $4.40 \mathrm{q}$ & $6.50 \mathrm{mn}$ & $8.50 \mathrm{ij}$ & $10.29 \mathrm{fg}$ & $11.52 \mathrm{~d}$ & $8.24 \mathrm{~B}$ \\
Chlorpropham (50 ppm) & $3.82 \mathrm{r}$ & $5.59 \mathrm{o}$ & $7.68 \mathrm{kl}$ & $8.87 \mathrm{i}$ & $10.69 \mathrm{ef}$ & $7.33 \mathrm{D}$ \\
Untreated (control) & $4.92 \mathrm{p}$ & $6.96 \mathrm{~m}$ & $9.52 \mathrm{~h}$ & $11.40 \mathrm{~d}$ & $12.33 \mathrm{c}$ & $9.03 \mathrm{~A}$ \\
Mean & $4.17 \mathrm{E}$ & $6.14 \mathrm{D}$ & $8.27 \mathrm{C}$ & $9.86 \mathrm{~B}$ & $11.26 \mathrm{~A}$ &
\end{tabular}

Means within a column followed by the same letter are not significantly different $(\mathrm{P}=0.05)$ according to Duncan's multiple range tests.

Inhibition of potato sprouting by mint oil may delay metabolic changes in tubers, perhaps because most of the loss tubers weight is due to evaporation through the buds during sprouting (Teper-Bamnolker et al., 2010).

Methyl jasmonate caused a retardation in growth of roots which in turn led to decreased transpiration in sweet potatoes and less weight loss (Frazier et al., 2004). Also, using essential oils reducing the respiration process rates during postharvest storage (Frazier et al., 2006; Shehata and Attia, 2014) for clove oil and Frazier et al. (2004) for mint or clove oil).

Teper-Bamnolker et al. (2010) found that Inhibition of potato sprouting during storage by thermal fogging with mint essential oil probably delays metabolic changes in potato tubers, leading to most of the treated tubers being marketable after more than 6 months of storage.
Sprout inhibition was strongly correlated to minimization of softening, probably because most of the tuber water loss is due to evaporation via the sprouts. During sprouting, tubers undergo a functional transition from active sink for assimilates to source of nutrients for the developing sprouts. The mobilization and transport of carbohydrates and other nutrients from the storage parenchyma into the growing buds is believed to cause weight loss and softening as well.

Concerning the interaction between postharvest treatments and storage periods, results indicated that sweet potato treated with Jasmine oil or CIPC was the most effective treatment in reducing the weight loss (\%) after 5 months +7 days shelf life of storage, followed by mint oil and clove oil. While untreated sweet potatoes (control) recorded high percentage of weight loss. 


\section{Sprouting (\%)}

Sprouts growth during storage decreases the quality and value of sweet potato roots for fresh market sales. Sprouting in particular leads to weight loss, reduction of nutritional, processing and marketable quality of roots (Sugri et al., 2017). Results presented in Table 2 indicated that sprouting $(\%)$ of the roots was initiated after 2 months at $13^{\circ} \mathrm{C}+7$ days at $20^{\circ} \mathrm{C}$ shelf life of storage in first season and after 3 months at $13^{\circ} \mathrm{C}+7$ days at $20^{\circ} \mathrm{C}$ shelf life of storage in the second season, the rate being slower initially than at the latter stages. By the 5 months +7 days shelf life of storage, it was the highest one. These results are in agreement with Adegoke and Odebad (2017).

No sprouts were observed in sweet potato roots treated with CIPC or jasmine oil until the end of storage period plus shelf life, while mint oil or clove oil reduced sprout percentage which valued $13.78 \%$ and $17.73 \%$, respectively (average of two years) at the end of storage period plus shelf life. However, untreated control reached sprouting $(40.4 \%$, average of two years) at the same period.

Methyl jasmonate (jasmine oil) is a naturally occurring substance which derives from linoleic acid (Vick and Zimmerman, 1984) and occurs ubiquitously in plants (Meyer et al., 1984).

The role of jasmine oil for preventing potato tuber sprouting during storage was explained by Platonova et al. (2010) as jasmine oil changed the ultrastructure of plasmalemma and plastid apparatus of eye meristematic cells and functioned together with other hormonal compounds (Dhaif Allah et al., 2018).

The effect of CIPC on inhibition of sprouting may be due to CIPC inhibits development by interfering with cell division through interrupting the spindle formation during active mitosis (Sugri et al., 2017). Cell division not only mandatory for sprout growth, but is also necessary to form the wound periderm during the wound- healing period in storage wound healing requires the production of three to ten cell layers resulting from cell division, consequently, CIPC must be applied after the wound-healing period is over, but before dormancy break or inhibition of sprout growth (Anonymous, 2001).

Clove oil does not have the efficacy on mode of action as CIPC, but it have ideal sprout suppressant properties for organic potatoes, potatoes designed into non-CIPC allowed markets, or to temporarily remove or blacken sprout just prior to marketing (Olsen et al., 2004). One benefit of using clove oil for sprouting control in storage is the ability to capitalize on the inherent dormancy of cultivar (Frazier et al., 2004).

CIPC acts as a mitotic inhibitor by interfering the process of spindle formation during cell division (Vaughn and Lehnen, 1991). It is known to inhibit protein synthesis, RNA synthesis, activity of $\beta$-amylase along with suppression of transpiration and respiration and interfere with of oxidative phosphorylation and photosynthesis (Vaughn and Lehnen, 1991). CIPC is considered as the most effective sprout suppressant for potatoes.

Carvone, 2-methyl-5-(1-methylethenyl)-2cyclohexene-1-one, is a member of monoterpenes and it is one of the most studied monoterpene to date for its effect on sprout growth suppression (De Carvalho and Da Fonseca, 2006). It can be found in many natural plant extracts, such as mint oil. A study conducted on wounded tuber tissues showed the presence of S-(+)-carvone prevented the activity of suberization and cambium layer formation (Oosterhaven et al., 1995). Mint essential oil application led to a local necrosis of the bud meristem and an induce of axillary bud growth in the same sprouting eye few weeks later. Furthermore, R-carvone caused great damage to the meristem membrane at sprout-inhibiting (Teper-Bamnolker et al., 2010).

According to Oosterhaven et al. (1995), $\mathrm{S}-(+)-$ Carvone plays a role in enhancing the degradation of 3- hydroxy-3-methylglutaryl coenzyme A reductase (HMG- CoA reductase), which is crucial for the biosynthesis of cytokinins, gibberellic acids, abscisic acid, membrane components and photosynthetic components. The possible mode of action of $\mathrm{S}-(+)$-Carvone at a molecular level was first elu-cidated from animal studies. A study done on rats showed that cyclic monoterpenes, lik 
Table 2. Effect of some essential oils and chlorpropham on sprouting (\%) of sweet potato roots during storage at $13^{\circ} \mathrm{C}$ plus 7 days at $20^{\circ} \mathrm{C}$ in $2017 / 2018$ and 2018/2019 seasons

\begin{tabular}{lcccccccc}
\hline Treatment & \multicolumn{7}{c}{ Storage period (month) + 7 days shelf life } \\
\cline { 2 - 8 } & Start & $\mathbf{1 + 7}$ days & $\mathbf{2 + 7}$ days & $\mathbf{3 + 7}$ days & $\mathbf{4 + 7}$ days & $\mathbf{5 + 7}$ days & Mean \\
\hline & & & \multicolumn{7}{c}{$\mathbf{2 0 1 7 / 2 0 1 8}$} \\
Jasmine oil (100 ppm) & $0.00 \mathrm{~g}$ & $0.00 \mathrm{~g}$ & $0.00 \mathrm{~g}$ & $0.00 \mathrm{~g}$ & $0.00 \mathrm{~g}$ & $0.00 \mathrm{~g}$ & $0.00 \mathrm{D}$ \\
Mint oil (100 ppm) & $0.00 \mathrm{~g}$ & $0.00 \mathrm{~g}$ & $0.00 \mathrm{~g}$ & $0.00 \mathrm{~g}$ & $3.32 \mathrm{fg}$ & $12.33 \mathrm{de}$ & $2.60 \mathrm{C}$ \\
Clove oil (100 ppm) & $0.00 \mathrm{~g}$ & $0.00 \mathrm{~g}$ & $0.00 \mathrm{~g}$ & $0.00 \mathrm{~g}$ & $6.22 \mathrm{f}$ & $18.33 \mathrm{~d}$ & $4.09 \mathrm{~B}$ \\
Chlorpropham (50 ppm) & $0.00 \mathrm{~g}$ & $0.00 \mathrm{~g}$ & $0.00 \mathrm{~g}$ & $0.00 \mathrm{~g}$ & $0.00 \mathrm{~g}$ & $0.00 \mathrm{~g}$ & $0.00 \mathrm{D}$ \\
Untreated (control) & $0.00 \mathrm{~g}$ & $0.00 \mathrm{~g}$ & $6.11 \mathrm{f}$ & $22.17 \mathrm{c}$ & $31.13 \mathrm{~b}$ & $41.00 \mathrm{a}$ & $16.74 \mathrm{~A}$ \\
Mean & $0.00 \mathrm{E}$ & $0.00 \mathrm{E}$ & $1.22 \mathrm{D}$ & $4.40 \mathrm{C}$ & $8.13 \mathrm{~B}$ & $14.30 \mathrm{~A}$ & \\
& & & & $2018 / 2019$ & & & \\
Jasmine oil (100 ppm) & $0.00 \mathrm{~d}$ & $0.00 \mathrm{~d}$ & $0.00 \mathrm{~d}$ & $0.00 \mathrm{~d}$ & $0.00 \mathrm{~d}$ & $0.00 \mathrm{~d}$ & $0.00 \mathrm{D}$ \\
Mint oil (100 ppm) & $0.00 \mathrm{~d}$ & $0.00 \mathrm{~d}$ & $0.00 \mathrm{~d}$ & $0.00 \mathrm{~d}$ & $8.14 \mathrm{c}$ & $15.22 \mathrm{~b}$ & $3.89 \mathrm{~B}$ \\
Clove oil (100 ppm) & $0.00 \mathrm{~d}$ & $0.00 \mathrm{~d}$ & $0.00 \mathrm{~d}$ & $0.00 \mathrm{~d}$ & $8.32 \mathrm{c}$ & $17.12 \mathrm{~b}$ & $4.24 \mathrm{~B}$ \\
Chlorpropham (50 ppm) & $0.00 \mathrm{~d}$ & $0.00 \mathrm{~d}$ & $0.00 \mathrm{~d}$ & $0.00 \mathrm{~d}$ & $0.00 \mathrm{~d}$ & $0.00 \mathrm{~d}$ & $0.00 \mathrm{D}$ \\
Untreated (control) & $0.00 \mathrm{~d}$ & $0.00 \mathrm{~d}$ & $0.00 \mathrm{~d}$ & $15.22 \mathrm{~b}$ & $27.11 \mathrm{a}$ & $39.81 \mathrm{c}$ & $13.69 \mathrm{~A}$ \\
Mean & $0.00 \mathrm{D}$ & $0.00 \mathrm{D}$ & $0.00 \mathrm{D}$ & $3.04 \mathrm{BC}$ & $8.71 \mathrm{~A}$ & $14.43 \mathrm{~A}$ & \\
\hline
\end{tabular}

Means within a column followed by the same letter are not significantly different $(\mathrm{P}=0.05)$ according to Duncan's multiple range tests.

cineole or menthol, reduced the activity of HMG-CoA reductase (Clegg et al., 1982). HMG-CoA reductase plays a vital role in plant growth and development. When radish seedlings were treated with an HMG-CoA reductase inhibitor, mevinolin, mevalonate starvation resulted in a complete inhibition in root elongation (Bach and Lichtenthaler, 1983).

Eugenol is the major component in clove oil, and may cause physical or chemical damage to sensitive sprouting tissues according (Kleinkopf and Frazier, 2002). The severe damage on the tissue is likely due to eugenol causing damage on cell membranes and subsequently resulting in loss of in membrane permeability (Tworkoski, 2002). Eugenol leads to physically damage the developing sprout and suppress sprout elongation (Kleinkopf $\boldsymbol{e t}$ al., 2003).

In this regards, the bioactive compound eugenol in clove oil is known as a sprouting suppressor via physical or chemical damaging of the developing buds affecting the lipid peroxidation and the enzymes activities of catalase, glutathione-S-transferase, peroxidase, polyphenol oxidase and superoxide dismutase (Afify et al., 2012).

Teper-Bamnolker et al. (2010) found that mint essential oil and its active chemical, the monoterpene R-carvone, inhibited sprout growth, probably via physical damage to the meristem tip; after the inhibitor's removal, the tuber sprouts through axillary bud growth.

\section{Decay Score}

Results in Table 3 show that, decay (score) of sweet potato significantly increased with the prolongation of storage period in the two seasons. The decayed roots started to be shown after 3 months at $13^{\circ} \mathrm{C}$ plus 7 days at $20^{\circ} \mathrm{C}$ and gave high score at the end of storage. These results are in agreement with those obtained by Hu and Tanaka (2007) they suggested that decay 
Zagazig J. Agric. Res., Vol. 46 No. (5) 2019

Table 3. Effect of some essential oils and chlorpropham on decay (score) of sweet potato roots during storage at $13^{\circ} \mathrm{C}$ plus 7 days at $20^{\circ} \mathrm{C}$ in $2017 / 2018$ and $2018 / 2019$ seasons

\begin{tabular}{lccccccc}
\hline Treatment & \multicolumn{7}{c}{ Storage period (month) + 7 days shelf life } \\
\cline { 2 - 8 } & Start & $\mathbf{1 + 7}$ days & $\mathbf{2 + 7}$ days & $\mathbf{3 + 7}$ days & $\mathbf{4 + 7}$ days & $\mathbf{5 + 7}$ days & Mean \\
\hline & & & & $\mathbf{2 0 1 7 / 2 0 1 8}$ & & & \\
Jasmine oil (100 ppm) & $1.00 \mathrm{e}$ & $1.00 \mathrm{e}$ & $1.00 \mathrm{e}$ & $1.00 \mathrm{e}$ & $1.00 \mathrm{e}$ & $1.00 \mathrm{e}$ & $1.00 \mathrm{D}$ \\
Mint oil (100 ppm) & $1.00 \mathrm{e}$ & $1.00 \mathrm{e}$ & $1.00 \mathrm{e}$ & $1.00 \mathrm{~d}$ & $1.00 \mathrm{c}$ & $2.67 \mathrm{bc}$ & $1.28 \mathrm{~B}$ \\
Clove oil (100 ppm) & $1.00 \mathrm{e}$ & $1.00 \mathrm{e}$ & $1.00 \mathrm{e}$ & $1.00 \mathrm{e}$ & $1.00 \mathrm{e}$ & $3.00 \mathrm{~b}$ & $1.33 \mathrm{~B}$ \\
Chlorpropham (50 ppm) & $1.00 \mathrm{e}$ & $1.00 \mathrm{e}$ & $1.00 \mathrm{e}$ & $1.00 \mathrm{e}$ & $1.00 \mathrm{e}$ & $2.00 \mathrm{c}$ & $1.17 \mathrm{C}$ \\
Untreated (control) & $1.00 \mathrm{e}$ & $1.00 \mathrm{e}$ & $1.00 \mathrm{e}$ & $2.00 \mathrm{c}$ & $3.33 \mathrm{~b}$ & $4.33 \mathrm{a}$ & $2.11 \mathrm{~A}$ \\
Mean & $1.00 \mathrm{D}$ & $1.00 \mathrm{D}$ & $1.00 \mathrm{D}$ & $1.20 \mathrm{C}$ & $1.1 .47 \mathrm{~B}$ & $2.60 \mathrm{~A}$ & \\
& & & & $\mathbf{2 0 1 8} / \mathbf{2 0 1 9}$ & & & \\
Jasmine oil (100 ppm) & $1.00 \mathrm{e}$ & $1.00 \mathrm{e}$ & $1.00 \mathrm{e}$ & $1.00 \mathrm{e}$ & $1.00 \mathrm{e}$ & $1.00 \mathrm{e}$ & $1.00 \mathrm{D}$ \\
Mint oil (100 ppm) & $1.00 \mathrm{e}$ & $1.00 \mathrm{e}$ & $1.00 \mathrm{e}$ & $1.00 \mathrm{e}$ & $1.00 \mathrm{e}$ & 2.00 & $1.45 \mathrm{C}$ \\
Clove oil (100 ppm) & $1.00 \mathrm{e}$ & $1.00 \mathrm{e}$ & $1.00 \mathrm{e}$ & $1.00 \mathrm{e}$ & $1.00 \mathrm{e}$ & 3.67 & $1.67 \mathrm{~B}$ \\
Chlorpropham (50 ppm) & $1.00 \mathrm{e}$ & $1.00 \mathrm{e}$ & $1.00 \mathrm{e}$ & $1.00 \mathrm{e}$ & 1.00 & 1.33 & $1.06 \mathrm{D}$ \\
Untreated (control) & $1.00 \mathrm{e}$ & $1.00 \mathrm{e}$ & $1.00 \mathrm{e}$ & 2.33 & $3.00 \mathrm{c}-\mathrm{e}$ & $4.33 \mathrm{a}$ & $2.11 \mathrm{~A}$ \\
Mean & $1.00 \mathrm{D}$ & $1.00 \mathrm{D}$ & $1.00 \mathrm{D}$ & $1.27 \mathrm{C}$ & $1.40 \mathrm{~B}$ & $2.47 \mathrm{~A}$ &
\end{tabular}

Means within a column followed by the same letter are not significantly different $(\mathrm{P}=0.05)$ according to Duncan's multiple range tests.

(score) increased in roots with the increase in storage period and that the activity of phenols was closely associated with the development. Similar results were reported by El-Sayed $\boldsymbol{e t}$ al. (2013).

All postharvest treatments were much better in reducing decay and thus longer storage periods. However, no decay were observed in sweet potato roots treated with jasmine oil until the end of storage period plus shelf life, while CIPC, mint oil and clove oil treatments reducing decay score during storage, at all of them no decay was observed in roots till four months at $13^{\circ} \mathrm{C}$ plus 7 days at $20^{\circ} \mathrm{C}$ and gave low decay at the end of storage plus shelf life comparing with control. These results are in agreement with Sugri et al. (2017) for CIPC, Adegoke and Odebad (2017) for clove oil, Frazier et al. (2004) and Dhaif Allah et al. (2018) for jasmine oil.
Frazier et al. (2004) found that significant reductions in disease severity rating and incidence when infected of potato tubers were treated with clove oil. Bong (2007) found that clove oil as essential oil enhanced phytotoxicity to sprouts and plant growth inhibiting activities and to posses' antiviral and antifungal activity exhibited fungicidal and antifungal activity for protecting potato tubers against sprouting altering taste or quality of the treated commodity.

Essential oils are water-insoluble and commonly contain a mixture of branched five carbon (isoprene) units referred as terpenes. Monoterpenes which consist of two isoprene units $\left(\mathrm{C}_{10}\right)$, represent the major components of essential oils (Buchanan et al., 2000). The presence of monoterpenes in plants often serves as a defense mechanism against insects and microorganisms (Vaughn and Spencer, 1991). Many essential oils and their major components, particularly carvone, have shown promising 
sprout suppression effects. Besides sprout suppression effects, carvone was also shown to be effective in inhibiting the growth of certain fungi and bacteria including Fusarium solani, Fusarium sulphureum, Streptococcus thermophilus, Lacto- coccus lactis and Escherichia coli (Song et al., 2008).

\section{General Appearance (Score)}

Results in Table 4 show that, the score of general appearance of sweet potato was deterioration during storage and the general appearance score dropped from excellent (9) to good or fair ("8" to "5") after 5 months +7 days shelf life of storage.

Concerning the effect of postharvest treatments, results revealed that there were significant differences between postharvest treatments and untreated (control) during storage plus shelf life. Sweet potato roots treated with all postharvest treatments had significantly the highest score of appearance as compared with untreated roots (control). However, roots treated with jasmine oil or chlorpropham were the most effective treatment for maintaining general appearance with significant differences between them in the two seasons, followed by clove oil and mint oil with no significant differences between them in the two seasons. While, untreated control recorded the lowest one in this concern. These results were in agreement with Dudai $\boldsymbol{e t}$ al. (2010) for mint oil, Shehata and Attia (2014) for clove oil and Dhaif Allah et al. (2018) for jasmine oil. Afify et al. (2012) showed that increased volatility of essential oils enhanced phytotoxicity to sprouts and plant growth inhibiting activities and to possess antiviral and antifungal activity exhibited fungicidal activity for protecting potato tubers against sprouting without altering taste or quality of the treated commodity.

In general, the interaction between postharvest treatments and storage periods plus shelf life was significant in the two seasons. Results recorded that sweet potato roots treated with jasmine oil showed the best appearance till 4 months at $13^{\circ} \mathrm{C}$ plus 7 days at $20^{\circ} \mathrm{C}$ and showed good appearance at the end of storage plus shelf life, while CIPC, clove oil and mint oil gave good appearance after 4 months at $13^{\circ} \mathrm{C}$ plus 7 days at $20^{\circ} \mathrm{C}$ and dropped to fair appearance at the end of storage period plus 7 days shelf life. On the other hand, untreated root (control) had the unsalable appearance at the same periods.

\section{Total Carotene Content}

Sweet potato is a rich crop with carotenoids and pro-Vitamin A. Carotenoids are yellow, orange or red pigments responsible for the color of many fruits, vegetables, and flowers. Orangeand yellow-fleshed sweet potato cultivars are excellent sources of carotenoids. $\beta$-carotene, $\alpha$-carotene, and $\beta$-cryptoxanthin are the major carotenoids found in sweet potato, of which $\beta$ carotene is the most abundant (Bengtsson et al., 2008).

Carotenoids have been linked with the enhancement of immune system and decreased risk of degenerative diseases such as cardiovascular problems, age-related macular degeneration and cataract formation (Byers and Perry, 1992).

Table 5 shows that total carotene content significantly reduced during storage period plus shelf life. These results were true in the two seasons and were in agreement with Emam and Attia (2010).

Concerning the effect of postharvest treatments, results revealed that all treatments were effective in maintaining total carotene content during storage compared with untreated (control). Moreover, roots treated with jasmine oil or CIPC were the most effective treatments in reducing the loss of total carotene content with no significant differences between them in the two seasons, followed by mint oil or clove oil treatments with no significant differences between them in the two seasons. The lowest value was obtained from untreated control (Table 5). These results were true in both seasons and were in agreement with Bengtsson et al. (2008). These results are in agreement with Sugri et al. (2017) for CIPC, Adegoke and Odebad (2017) for clove oil, Frazier et al. (2004) and Dhaif Allah et al. (2018) for jasmine oil.

For the interaction between postharvest treatments and storage period, after 5 months + 7 days shelf life, results indicated that sweet potato roots treated with jasmine oil or CIPC had significantly higher values of total carotene content compared with other treatments, followed by mint oil and clove oil with no significant differences between them. These results were true in both seasons (Table 5). 
Table 4. Effect of some essential oils and chlorpropham on general appearance (score) of sweet potato roots during storage at $13^{\circ} \mathrm{C}$ plus 7 days at $20^{\circ} \mathrm{C}$ in $2017 / 2018$ and $2018 / 2019$ seasons

\begin{tabular}{|c|c|c|c|c|c|c|c|}
\hline \multirow[t]{2}{*}{ Treatment } & \multicolumn{7}{|c|}{ Storage period (month) +7 days shelf life } \\
\hline & Strat & $1+7$ days & $2+7$ days & $3+7$ days & 4+7 days & $5+7$ days & Mean \\
\hline & & \multicolumn{6}{|c|}{$2017 / 2018$} \\
\hline Jasmine oil (100 ppm) & $9.00 \mathrm{a}$ & $9.00 \mathrm{a}$ & $9.00 \mathrm{a}$ & $9.00 \mathrm{a}$ & $8.33 \mathrm{ab}$ & $7.67 \mathrm{a}-\mathrm{c}$ & $8.67 \mathrm{~A}$ \\
\hline Mint oil (100 ppm) & $9.00 \mathrm{a}$ & $9.00 \mathrm{a}$ & $7.67 \mathrm{a}-\mathrm{c}$ & $7.67 \mathrm{a}-\mathrm{c}$ & $7.00 \mathrm{a}-\mathrm{d}$ & $5.67 \mathrm{bd}$ & $7.66 \mathrm{C}$ \\
\hline Clove oil (100 ppm) & $9.00 \mathrm{a}$ & $9.00 \mathrm{a}$ & $7.67 \mathrm{a}-\mathrm{c}$ & $7.67 \mathrm{a}-\mathrm{c}$ & $7.00 \mathrm{a}-\mathrm{d}$ & $5.00 \mathrm{bd}$ & $7.55 \mathrm{C}$ \\
\hline Chlorpropham (50 ppm) & $9.00 \mathrm{a}$ & $9.00 \mathrm{a}$ & $9.00 \mathrm{a}$ & $9.00 \mathrm{a}$ & $8.33 \mathrm{ab}$ & $6.33 \mathrm{ab}$ & $8.44 \mathrm{~B}$ \\
\hline Untreated (control) & $9.00 \mathrm{a}$ & $9.00 \mathrm{a}$ & $7.00 \mathrm{a}-\mathrm{d}$ & $6.33 \mathrm{a}-\mathrm{d}$ & $3.00 \mathrm{c}-\mathrm{e}$ & $1.00 \mathrm{f}$ & $5.88 \mathrm{D}$ \\
\hline \multirow[t]{2}{*}{ Mean } & $9.00 \mathrm{~A}$ & $9.00 \mathrm{~A}$ & $8.07 \mathrm{~B}$ & $7.93 \mathrm{BC}$ & $6.73 \mathrm{D}$ & $5.13 \mathrm{D}$ & \\
\hline & & \multicolumn{6}{|c|}{ 2018/2019 } \\
\hline Jasmine oil (100 ppm) & $9.00 \mathrm{a}$ & $9.00 \mathrm{a}$ & $9.00 \mathrm{a}$ & $9.00 \mathrm{a}$ & $7.67 a-b$ & $7.67 a-b$ & $8.55 \mathrm{~A}$ \\
\hline Mint oil (100 ppm) & $9.00 \mathrm{a}$ & $9.00 \mathrm{a}$ & $7.67 \mathrm{a}-\mathrm{c}$ & $7.00 \mathrm{a}-\mathrm{d}$ & 7.00 c-e & $5.00 \mathrm{~d}-\mathrm{f}$ & $7.45 \mathrm{C}$ \\
\hline Clove oil (100 ppm) & $9.00 \mathrm{a}$ & $9.00 \mathrm{a}$ & $7.67 \mathrm{a}-\mathrm{c}$ & $6.33 \mathrm{~b}-\mathrm{e}$ & 7.00 c-e & $5.00 \mathrm{~d}-\mathrm{f}$ & $7.33 \mathrm{C}$ \\
\hline Chlorpropham (50 ppm) & $9.00 \mathrm{a}$ & $9.00 \mathrm{a}$ & $9.00 \mathrm{a}$ & $8.33 \mathrm{ab}$ & $7.67 \mathrm{a}-\mathrm{c}$ & $6.33 \mathrm{~b}-\mathrm{c}$ & $8.22 \mathrm{~B}$ \\
\hline Untreated (control) & $9.00 \mathrm{a}$ & $9.00 \mathrm{a}$ & $7.00 \mathrm{a}-\mathrm{d}$ & $7.00 \mathrm{a}-\mathrm{d}$ & $3.00 \mathrm{e}-\mathrm{g}$ & $1.00 \mathrm{~h}$ & $6.00 \mathrm{D}$ \\
\hline Mean & $9.00 \mathrm{~A}$ & $9.00 \mathrm{~A}$ & $8.07 \mathrm{~B}$ & $7.53 \mathrm{C}$ & $6.47 \mathrm{D}$ & $5.00 \mathrm{E}$ & \\
\hline
\end{tabular}

Means within a column followed by the same letter are not significantly different $(\mathrm{P}=0.05)$ according to Duncan's multiple range tests.

Table 5. Effect of some essential oils and chlorpropham on total carotene content $(\mathrm{mg} / 100 \mathrm{~g}$ fw) of sweet potato roots during storage at $13^{\circ} \mathrm{C}$ plus 7 days at $20^{\circ} \mathrm{C}$ in $2017 / 2018$ and 2018/2019 seasons

\begin{tabular}{lccccccc}
\hline Treatment & \multicolumn{7}{c}{ Storage period (month) + 7 days shelf life } \\
\cline { 2 - 9 } & Start & $\mathbf{1 + 7}$ days & $\mathbf{2 + 7}$ days & $\mathbf{3 + 7}$ days & $\mathbf{4 + 7}$ days & $\mathbf{5 + 7}$ days & Mean \\
\hline & & \multicolumn{7}{c}{$2017 / 2018$} \\
Jasmine oil (100 ppm) & $15.77 \mathrm{a}$ & $14.40 \mathrm{~cd}$ & $13.37 \mathrm{e}$ & $12.55 \mathrm{~g}$ & $11.41 \mathrm{hi}$ & $10.55 \mathrm{j}$ & $13.00 \mathrm{~A}$ \\
Mint oil (100 ppm) & $15.77 \mathrm{a}$ & $14.23 \mathrm{~cd}$ & $13.10 \mathrm{ef}$ & $12.80 \mathrm{fg}$ & $11.30 \mathrm{i}$ & $9.28 \mathrm{k}$ & $12.75 \mathrm{~B}$ \\
Clove oil (100 ppm) & $15.77 \mathrm{a}$ & $14.57 \mathrm{~b}-\mathrm{d}$ & $14.00 \mathrm{~d}$ & $12.50 \mathrm{e}$ & $10.63 \mathrm{hi}$ & $9.32 \mathrm{k}$ & $12.80 \mathrm{~B}$ \\
Chlorpropham (50 ppm) & $15.77 \mathrm{a}$ & $14.43 \mathrm{~cd}$ & $13.47 \mathrm{e}$ & $12.50 \mathrm{~g}$ & $11.45 \mathrm{hi}$ & $10.50 \mathrm{j}$ & $13.02 \mathrm{~A}$ \\
Untreated (control) & $15.77 \mathrm{a}$ & $14.17 \mathrm{a}$ & $11.86 \mathrm{ab}$ & $10.89 \mathrm{fg}$ & $9.76 \mathrm{~h}$ & 8.481 & $11.82 \mathrm{C}$ \\
Mean & $15.77 \mathrm{~A}$ & $14.36 \mathrm{~B}$ & $13.16 \mathrm{C}$ & $12.25 \mathrm{D}$ & $10.91 \mathrm{E}$ & $9.63 \mathrm{~F}$ & \\
& & \multicolumn{7}{c}{$\mathbf{2 0 1 8} / 2019$} \\
Jasmine oil (100 ppm) & $16.08 \mathrm{a}$ & $14.60 \mathrm{c}$ & $13.70 \mathrm{~d}$ & $12.45 \mathrm{f}$ & $11.60 \mathrm{~g}$ & $10.80 \mathrm{~h}$ & $13.21 \mathrm{~A}$ \\
Mint oil (100 ppm) & $16.08 \mathrm{a}$ & $14.40 \mathrm{c}$ & $13.35 \mathrm{~d}$ & $12.63 \mathrm{ef}$ & $11.47 \mathrm{ng}$ & $9.41 \mathrm{ij}$ & $12.89 \mathrm{~B}$ \\
Clove oil (100 ppm) & $16.08 \mathrm{a}$ & $14.70 \mathrm{a}-\mathrm{c}$ & $14.35 \mathrm{c}$ & $12.59 \mathrm{~d}$ & $10.77 \mathrm{~g}$ & $9.38 \mathrm{j}$ & $12.97 \mathrm{~B}$ \\
Chlorpropham (50 ppm) & $16.08 \mathrm{a}$ & $14.63 \mathrm{bc}$ & $13.72 \mathrm{~d}$ & $12.50 \mathrm{f}$ & $11.57 \mathrm{~g}$ & $10.78 \mathrm{hi}$ & $13.21 \mathrm{~A}$ \\
Untreated (control) & $16.08 \mathrm{a}$ & $14.03 \mathrm{a}$ & $10.80 \mathrm{ab}$ & $9.91 \mathrm{e}$ & $9.65 \mathrm{~g}$ & $8.67 \mathrm{~m}$ & $11.52 \mathrm{C}$ \\
Mean & $16.08 \mathrm{~A}$ & $14.47 \mathrm{~B}$ & $13.18 \mathrm{C}$ & $12.02 \mathrm{D}$ & $11.02 \mathrm{E}$ & $9.81 \mathrm{~F}$ & \\
\hline
\end{tabular}

Means within a column followed by the same letter are not significantly different $(\mathrm{P}=0.05)$ according to Duncan's multiple range tests. 


\section{Total Sugars Content}

With respect to storage period, results indicate that total sugars were increased with prolongation storage period up to 2 months +7 days shelf life then it began to decrease (Table 6). The increment in sugar at the first period of storage might due to the moisture loss through transpiration and the conversion of starch to sugars. But the reduction at the end of storage might owe to the utilization of sugars in respiration (Wanas et al., 1993). Zhang et al. (2002) found that glucose and sucrose increased early in storage and then remained fairly constant. In sweet potato roots $\alpha$-amylase plays a key role in starch degradation during storage. Transformation of starch to sugar in sweet potato takes place during curing and continues in storage (Picha, 1986). These results are in line with Emam and Attia (2010) on sweet potato.
All postharvest treatments had significantly the highest value of total sugar content as compared with untreated roots (control) during storage plus shelf life. Roots treated with jasmine oil retained more total sugars contents followed by mint oil or clove oil. However, CIPC treatment was less effective in this concern. The lowest value of total sugars content was obtained from untreated roots (control). These results were achieved in both seasons and were in agreement with Sugri et al. (2017) for CIPC, Adegoke and Odebad (2017) for clove oil, Frazier et al. (2004) Dhaif Allah et al. (2018) for jasmine acid).

Concerning the interaction of used treatments and storage periods after 5 months at $13^{\circ} \mathrm{C}+7$ days at $20^{\circ} \mathrm{C}$, results revealed that all treatments gave the higher total sugars content with no significant differences between them in the second season than control (Table 6).

Table 6. Effect of some essential oils and chlorpropham on total sugars content $(\mathrm{g} / 100 \mathrm{~g} f \mathrm{fw})$ of sweet potato roots during storage at $13^{\circ} \mathrm{C}$ plus 7 days at $20^{\circ} \mathrm{C}$ in $2017 / 2018$ and 2018 / 2019 seasons

\begin{tabular}{lcccccccc}
\hline Treatment & \multicolumn{7}{c}{ Storage period (month) + 7 days shelf life } \\
\cline { 2 - 9 } & Start & $\mathbf{1 + 7}$ days & $\mathbf{2 + 7}$ days & $\mathbf{3 + 7}$ days & $\mathbf{4 + 7}$ days & $\mathbf{5 + 7}$ days & Mean \\
\hline & & & & $2017 / 2018$ \\
Jasmine oil (100 ppm) & $6.91 \mathrm{a}$ & $6.80 \mathrm{ab}$ & $6.85 \mathrm{ab}$ & $6.91 \mathrm{a}$ & $6.30 \mathrm{a}-\mathrm{g}$ & $5.87 \mathrm{e}-\mathrm{j}$ & $6.62 \mathrm{~A}$ \\
Mint oil (100 ppm) & $6.91 \mathrm{a}$ & $6.63 \mathrm{a}-\mathrm{e}$ & $6.91 \mathrm{a}$ & $6.67 \mathrm{a}-\mathrm{d}$ & $6.03 \mathrm{c}-\mathrm{h}$ & $5.61 \mathrm{~g}-\mathrm{k}$ & $6.46 \mathrm{~B}$ \\
Clove oil (100 ppm) & $6.91 \mathrm{a}$ & $6.70 \mathrm{a}-\mathrm{c}$ & $6.86 \mathrm{ab}$ & $6.62 \mathrm{a}-\mathrm{e}$ & $5.96 \mathrm{~d}-\mathrm{i}$ & $5.67 \mathrm{f}-\mathrm{k}$ & $6.45 \mathrm{~B}$ \\
Chlorpropham (50 ppm) & $6.91 \mathrm{a}$ & $6.42 \mathrm{a}-\mathrm{f}$ & $6.50 \mathrm{a}-\mathrm{e}$ & $6.10 \mathrm{~b}-\mathrm{h}$ & $5.60 \mathrm{~g}-\mathrm{k}$ & $5.27 \mathrm{i}-\mathrm{k}$ & $6.13 \mathrm{C}$ \\
Untreated (control) & $6.91 \mathrm{a}$ & $6.35 \mathrm{a}-\mathrm{g}$ & $6.47 \mathrm{a}-\mathrm{e}$ & $6.00 \mathrm{c}-\mathrm{i}$ & $5.20 \mathrm{~h}-\mathrm{k}$ & $4.81 \mathrm{jk}$ & $5.96 \mathrm{D}$ \\
Mean & $6.91 \mathrm{~A}$ & $6.58 \mathrm{AB}$ & $6.72 \mathrm{~A}$ & $6.46 \mathrm{~B}$ & $5.88 \mathrm{C}$ & $5.51 \mathrm{D}$ & \\
& & & & $\mathbf{2 0 1 8} / \mathbf{2 0 1 9}$ & & & \\
Jasmine oil (100 ppm) & $7.41 \mathrm{a}$ & $7.13 \mathrm{ab}$ & $7.18 \mathrm{ab}$ & $7.24 \mathrm{a}$ & $6.30 \mathrm{a}-\mathrm{e}$ & $6.20 \mathrm{a}-\mathrm{f}$ & $6.87 \mathrm{~A}$ \\
Mint oil (100 ppm) & $7.41 \mathrm{a}$ & $6.96 \mathrm{a}-\mathrm{c}$ & $7.24 \mathrm{a}$ & $7.00 \mathrm{a}-\mathrm{c}$ & $6.37 \mathrm{a}-\mathrm{e}$ & $5.94 \mathrm{a}-\mathrm{f}$ & $6.82 \mathrm{~B}$ \\
Clove oil (100 ppm) & $7.41 \mathrm{a}$ & $7.03 \mathrm{a}-\mathrm{c}$ & $7.19 \mathrm{ab}$ & $6.95 \mathrm{a}-\mathrm{c}$ & $6.29 \mathrm{a}-\mathrm{f}$ & $6.00 \mathrm{a}-\mathrm{f}$ & $6.81 \mathrm{~B}$ \\
Chlorpropham (50 ppm ) & $7.41 \mathrm{a}$ & $6.68 \mathrm{a}-\mathrm{c}$ & $6.80 \mathrm{a}-\mathrm{c}$ & $6.33 \mathrm{a}-\mathrm{e}$ & $5.87 \mathrm{a}-\mathrm{f}$ & $5.47 \mathrm{c}-\mathrm{f}$ & $6.43 \mathrm{C}$ \\
Untreated (control) & $7.41 \mathrm{a}$ & $6.75 \mathrm{a}-\mathrm{c}$ & $5.83 \mathrm{a}-\mathrm{c}$ & $5.13 \mathrm{a}-\mathrm{d}$ & $4.93 \mathrm{a}-\mathrm{f}$ & $4.05 \mathrm{~b}-\mathrm{f}$ & $5.68 \mathrm{D}$ \\
Mean & $7.41 \mathrm{~A}$ & $6.91 \mathrm{~B}$ & $6.85 \mathrm{C}$ & $6.53 \mathrm{D}$ & $5.95 \mathrm{E}$ & $5.53 \mathrm{~F}$ &
\end{tabular}

Means within a column followed by the same letter are not significantly different $(\mathrm{P}=0.05)$ according to Duncan's multiple range tests. 
Clove oil and its major bioactive constituent, eugenol, have the ability to slow down carbohydrates and protein degradation by interfering with the hydrolysis and energy enzymes. As reported by Solgi and Ghorbanpour (2014) the hydroxyl group on eugenol is thought to bind to proteins, preventing the enzyme activity.

The reduction of total sugars loss of roots during storage by using essential oils (jasmine, mint or clove) may be attributed to reducing respiration process rates during storage, which slow down the metabolic processes, resulted in reducing consumption of total sugars during storage (Song et al., 2008).

\section{Conclusion}

The results suggest that sweet potato roots cv. Beauregard treated with jasmine oil at 100 ppm is a promising as natural alternative to CIPC for controlling sprouting, maintenance quality and gave good appearance of roots after 5 months of storage at $13^{\circ} \mathrm{C}$ plus 7 days at $20^{\circ} \mathrm{C}$ (shelf life) without decay.

\section{REFERENCES}

Adegoke, G.O. and A.O. Odebad (2017). Control of Sprouting of Yam (Dioscorea rotundata) and Sweet Potato (Ipomoea batatas) using African Cardamon (Aframomum danielli), Turmeric (Curcuma longa) and Clove (Syzygium aromaticum). J. Food Industry, $1: 1$.

Afek, U. and S. Warshavsky (1998). Problems in storage of potatoes in Israel. In: Levey, D (ed). Potato in Hot Climate. Israel Agres. J. Agric. Res. Organization (in Hebrew, English abstracts)Agri. Res. Org. (ARO). The Volcani Cent. Israel, 9 : 97-114.

Afify, A.E.M.M., H.S. El-Beltagi, A.A. Aly and A.E. El-Ansary (2012). Antioxidant enzyme activities and lipid peroxidation as biomarker for potato tuber stored by two essential oils from Caraway and Clove and its main component carvone and eugenol. Asian Pacific J. Trop. Biomed., 2 (2): 5772-5780.

AOAC (1975). Official Methods of Analysis, $12^{\text {th }}$ Ed. Association of Official Analytical Chemists, Washington, DC, 597.
Anonymous (2001). DECCO 271 Aerosol potato sprout inhibitor lable ELF Atochem North America. Monrovia, CA,USA, 1-2.

Bach, T.J. and H.K. Lichtenthaler (1983). Inhibition by mevinolin of plant-growth, sterol formation and pigment accumulation. Physiol. Plant., 59 (1): 50-60.

Bengtsson, A., A. Namutebi, L.M. Alminger and U. Svanberg (2008). Effects of various traditional processing methods on the alltrans- $\beta$-carotene content of orange-fleshed sweet potato. J. Food Comp. and Anal., 21: 134-143.

Bong, U. (2007). Screening of natural plant volatiles to control the potato (solanum tuberosum) pathogens helminothosporium solani, fusarium solani, phoma faveata and rizoctonia solani. Potato Res,, 50 (2): 185203.

Buchanan, B.B., W. Gruissem and R.L. Jones (Eds.) (2000). Biochemistry and Mole- cular Biology of Plants, The American Society of Plant Physiologists, Rock- ville, MD, USA, 1252-1265.

Buitelaar, N. (1987). Sprout inhibition in ware potato storage. In: Rastovski, A and A.van Es (eds), storage of potatoes: post-harvest behavior, store design, storage practice, handling Pudoc, Wageningen, the Netherlands, 331-341.

Byers, T. and G. Perry (1992). Dietary carotenes, vitamin $\mathrm{C}$, and vitamin $\mathrm{E}$ as protective antioxidants in human cancers. Ann. Rev. Nutr., 12 (1): 139-159.

Clegg, R.J., B. Middleton, G.D. Bell and D.A. White (1982). The mechanism of cyclic monoterpene inhibition of hepatic 3-hydroxy3-methylglutaryl coenzyme-a reductase in vivo in the rat. J. Biol. Chem., 257 (5): 22942299.

Coleman, W.K., G. Lonergan and P. Silk (2001). Potato sprout growth suppression by menthone and neomenthol, volatile oil components of Minthostachys, Satureja, Bystropogon, and Mentha species. Ame. J. Potato Res., 78: 345-354.

De Carvalho, C.C.C.R. and M.M.R. Da Fonseca (2006). Carvone: Why and how should one 
bother to produce this terpene. Food Chem., 95: 413-422.

Dhaif Allah, M.S., F.I. El-Adgham, S.M. ElAraby and I.M. Ghoneim (2018). Influence of jasmonic acid and chlorpropham treatments on sprouting, quality and storability of potato tubers during cold storage. Alex. J. Agric. Sci., 63 (5): 303-311.

Dudai, N., O. Larkov, E. Putievsky, H.R. Lerner, U. Ravid, E. Lewinsohn and A.M. Mayer (2010). Biotransformation of constituents of essential oils by germinating wheat seed. Phytochem., 55 : 375-382.

Elbashir, H.A., R.A. Ahmed and K.S. Yousif (2011). Effect of spearmint oil on sprouting and processing quality of diamant and sinora Potato Varieties. J. Biol. Sci., 3 (5): 530-534.

Elsadr, H. and D. Waterer (2005). Efficacy of natural compounds to suppress sprouting and fusarium dry rot in potatoes. Univ. Saskatchewan, Dept. Plant Sci., 51 Campus Drive Sakatoon, Saskatchewan, Canada, S7N5A8.

El-Sayed, S.F., M.A. El-Helaly, M.S. Emam and M.A. Abdel-Ghaffar (2013). Effect of some post-cold storage treatments on shelf life of sweet potato roots. J. Hort. Sci. and Ornamen. Plants, 5 (3): 160-170.

Emam, M.S. and M.M. Attia (2010). Influence of harvesting date and some postharvest treatments on quality and storage ability of sweet potato roots. Ann. Agric. Sci., Moshtohor, 48 (2): 175-185.

Frazier, M.J., N. Olsen and G.E. Kleinkopf (2004). Organic and alternative methods for potato sprout control in storage. Univ. Idaho, College of Agric. and life. Sci., Idaho CIS 1120. Available at http:// www. extension.uidaho.edu/publishing/pdf/CIS/CIS 1120. pdf.

Frazier, M.G., G.E. Kleinkopf and N.L. Olsen (2006). Clove oil for potato sprout and silver scurf suppression in storage. Presented at the Idaho Potato Conf. Jan. 19.2012.

Hu, W. and S. I. Tanaka (2007). Effects of heat treatment on the quality and storage life of sweet potato. J. Sci. Food and Agric., 87: 313-319.

Kleinkopf, G.E. and M.J. Frazier (2002). Alternative sprout suppression for stored potatoes. Univ. Idaho, College of Agri. and Life Sci. Proceedings: Winter Com. Schools, 34: 183-187.

Kleinkopf, G.E., N.A. Oberg and N.L. Olsen (2003). Sprout inhibition in storage: current status, new chemistries and natural compounds. Ame. J. Potato Res., 80 : 317-327.

Matissek, K., F.M. Schnepel and G. Steiner (1992). Food materials analyses. Springer lehrbuch, 440.

Meyer, A., O. Miresch, C. Buttner, W. Dathe and G. Sembdner (1984). Occurrence of plant growth regulator jasmonic acid in plants. J. Plant Growth Regul, 3: 1-8.

Olsen, N., M.J. Fraizer and G. Kleinkoph (2004). Potato sprout suppression from clove oil. Univ. Idahoo Extension. www. Kimberly. Undaho.edu/Potatoes/Cloveoil80 6.pdf.

Oosterhaven, K., K.J. Hartmans and J.J.C. Scheffer (1995). Inhibition of potato sprout growth by carvone enantiomers and their bioconversion in sprouts. Potato Res., 38: 219-230.

Parthier, B. (1991). Jasmonates, new regulators of plant growth and development: many facts and few hypotheses on their actions. Bot. Acta, 104: 446-454.

Picha, D.H. (1986). Weight loss in sweet potatoes during curing and storage. Contribution of transpiration and respiration. J. Ame. Soc. Hort. Sci., 111 (6): 889-892.

Platonova, T.A., A.S. Evsyunina and N.P. Korableva (2010). Changes in the plastid apparatus of apical meristem cells of potato tubers upon growth regulation with jasmonic acid. Appl. Biochem. Microbiol., 46 : $352-$ 358.

Shehata, S.A. and M.M. Attia (2014). Effect of some alternative natural compounds for potato sprout control during storage. Ann. Agric. Sci. Moshtohor, 52 (1): 47- 55. 
Snedecor, C.W. and W.G. Cochran (1982). Statistical Methods, $7^{\text {th }}$ Ed. The Iowa State Univ. Press. Ames. Iowa, USA.

Solgi, M. and M. Ghorbanpour (2014). Application of essential oils and their biological effects on extending the shelf-life and quality of horticultural crops. Trakia J. Sci., 2 : 198-210.

Song, X. (2009). The impact of dill weed, spearmint and clove essential oil on sprout suppression in potato tubers (Doctoral dissertation, University of Saskatchewan).

Song, X., M.S. Bandara and K.K. Tanino (2008). Potato dormancy regulation: Use of essential oils for sprout suppression in potato storage. Fruit Veg. Cereal Sci. Biotechnol, 2: 110-117.

Sugri, I., B.K. Maalekuu, F. Kusi and E. Gaveh (2017). Quality and shelf-life of sweet potato as influenced by storage and postharvest treatments. Trends Hort. Res., 7: 1-10.

Teper-Bamnolker, P., N. Dudai, R. Fischer, E. Belausov, H. Zemach, O. Shoseyov and D. Eshel (2010). Mint essential oil can induce or inhibit potato sprouting by differential alteration of apical meristem. Planta, 232 (1): 179-186.

Tworkoski, T. (2002). Herbicide effects of essential oils. Weed Sci., 50: 425-31.

Vaughn S.F. and G.F. Spencer (1991). Volatile monoterpenes inhibit potato tuber sprouting. Ame. Potato J., 68 (12): 821-831.
Vaughn, K.C. and L.P. Lehnen (1991). Mitotic disrupter herbicides. Weed Sci., 39:450-457.

Vick, B.A. and D.C. Zimmerman (1984). Biosynthesis of jasmonic acid by several plant species. Plant Physiol., 75: 458-461.

Wanas, N.M., T.M. El-Sheikh and R.A. ElBedewy (1993). Effect of nitrogen fertilizer on yield, storage ability and quality of new variety of sweet potato. Zagazig J. Agric. Res., 20 (2B): 773-783.

Wang, C.Y. (1998). Methyl jasmonate inhibits postharvest sprouting and improves storage quality of radishes. Postharvest Biol. and Technol., 14 (2): 179-183.

Wenzhong, H., T.S. Ichiro and H. Yoshiaki (2004). Effect of heat treatment on quality of sweet potato in wrapper type cold store during long-term storage. J. Fac. Agr. Kyilshu Univ., 49 (1): 129 -138.

Yada, R.Y., R.H. Coffin, M.K. Keenan, M. Fitts, C.D. Ufault and G.C.C. Tai (1991). The effect of maleic hydrazide (potassium salt) on potato yield, sugar content and chip color of Kennebec and Norchip cultivars. Ame. Potato J., 68: 705-709.

Zhang, Z., C.C. Wheatley and H. Corke (2002). Biochemical changes during storage of sweet potato roots differing in dry matter content. Postharvest Biol. Technol., 24: 317-325. 


$$
\text { قسم بحوث تداول الخضر ـ معهد بحوث البساتين ـ مركز البحوث الزمد الزباح راعية ـ الجيزة ـ مصر }
$$

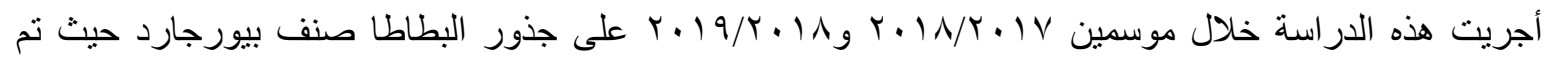

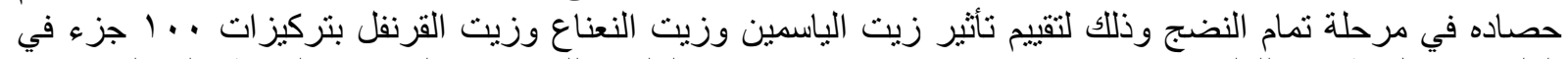

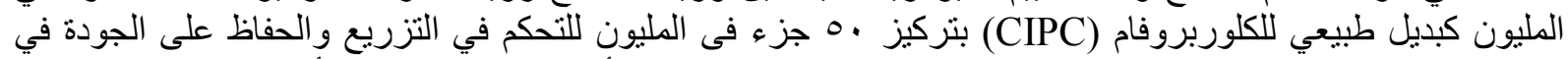

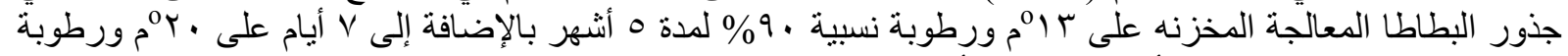

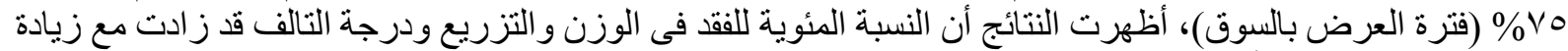

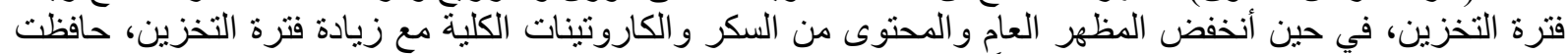

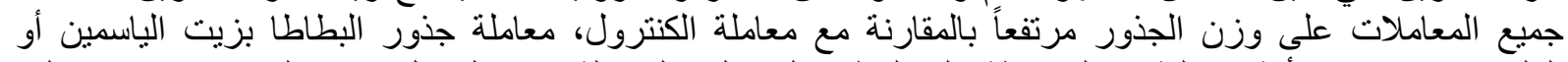

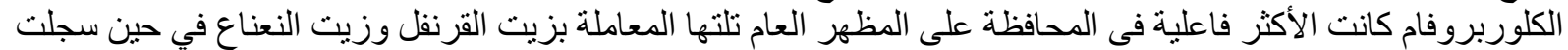

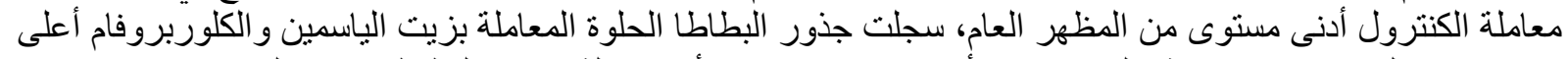

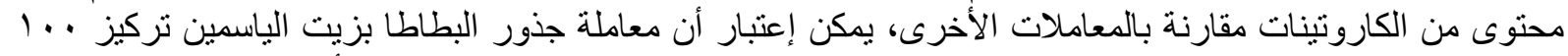

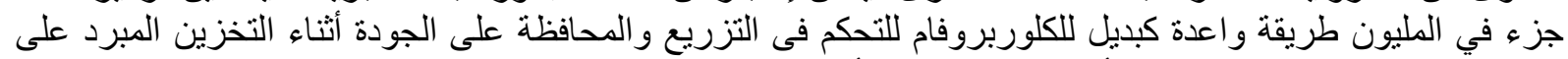

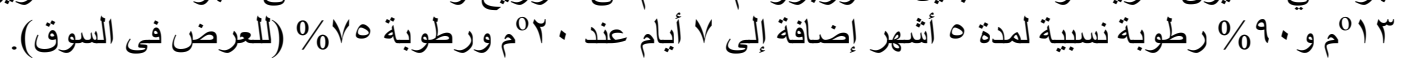

